\title{
Accumulation of heavy metals from soil in medicinal plants
}

\author{
Nina Kočevar Glavač ${ }^{1}$, Svetlana Djogo ${ }^{3}$, Slavica Ražić3 ${ }^{3}$,Samo Kreft ${ }^{1}$, and Marjan Veber $^{2}$ \\ Department of Pharmaceutical Biology, Faculty of Pharmacyl', Department of Analytical Chemistry, Faculty of \\ Chemistry and Chemical Technology², University of Ljubljana, Ljubljana, Slovenia, Faculty of Pharmacy, Institute of \\ Analytical Chemistry, University of Belgrade, Belgrade, Serbia ${ }^{3}$
}

[Received in May 2017; Similarity Check in May 2017; Accepted in August 2017]

Medicinal plants accumulate heavy metals from contaminated soil, and their consumption can cause poisoning. Our objective was to determine the levels of $\mathrm{Pb}, \mathrm{Cd}, \mathrm{Zn}, \mathrm{Cu}, \mathrm{Fe}$, and $\mathrm{Mn}$ in four medicinal plant species (Achillea millefolium, Hypericum perforatum, Plantago lanceolata, and Urtica dioica) and their native soil, all sampled at a former smelter. The highest soil $\mathrm{Cd}, \mathrm{Pb}$, and $\mathrm{Zn}$ levels surpassed the maximum allowed limit 75-fold, 48-fold, and 14-fold, respectively. Their soil levels correlated with those in the plants, but this was not the case with $\mathrm{Cu}, \mathrm{Fe}$, and Mn. Heavy metal accumulation seems to depend on the plant species, yet even so, medicinal herbs should be cultivated and gathered only from controlled (uncontaminated) areas. Polluted areas should be monitored on a regular basis, while further research should investigate the connection between the heavy metal levels in the soil, their levels available for plants, and the levels extractable from plants.

KEY WORDS: Achillea millefolium; contamination; Hypericum perforatum; Plantago lanceolata; Urtica dioica

Over the past several decades, industrial activity in the mining and smelting sectors has caused serious environmental pollution by heavy metals on a global scale. Increased concentrations of heavy metals in the air, soil, or water threatens human health both directly and indirectly via accumulation in the food chain. In countries with high ecological awareness the risk of acute exposure has been minimised thanks to the enforcement of restoration laws and policies. The risk of chronic effects, however, is still there.

Heavy metals in herbal medicines and spices, especially if cultivated or collected in contaminated areas, often exceed safety limits and are an important source of exposure through diet (1-4). Accumulation of heavy metals in plants (i.e. phytoextraction) has been well investigated under laboratory conditions (5). However, it is also important to correlate metal levels in plants and the soil in which these plants grow.

In our research we focused on soil heavy metal pollution in the Meža Valley, Slovenia. This area had been heavily affected by mining and smelting operations in the town of Žerjav. Lead production started in the $16^{\text {th }}$ century and intensified in the $20^{\text {th }}$ century, reaching as much as $1 \%$ of the global production (6). In the late 1970s, extensive restoration efforts were introduced, and 20 years later, mining was discontinued (6).

Correspondence to: Nina Kočevar Glavač, Faculty of Pharmacy, University of Ljubljana, Aškerčeva cesta 7, 1000 Ljubljana, Slovenia

E-mail:nina.kocevar.glavac@ffa.uni-lj.si
Environmental pollution in this area, including biological burden, has been monitored regularly since the 1980s (6-11). Restoration efforts were intensified in 2007 and brought important improvements in the living conditions ever since. However, the parameters of chronic human exposure, such as the concentrations of heavy metals in blood and in the soil, are still alarming $(6,12)$.

The aim of this study was to gain the latest insight into the levels of heavy metal pollution of the Meža Valley and to look for a correlation between the levels of lead $(\mathrm{Pb})$, cadmium $(\mathrm{Cd})$, zinc $(\mathrm{Zn})$, copper $(\mathrm{Cu})$, iron $(\mathrm{Fe})$, and manganese (Mn) in soil and four common medicinal plants grown in the same locales, i.e. common yarrow (Achillea millefolium), St. John's wort (Hypericum perforatum), ribwort plantain (Plantago lanceolata), and common nettle (Urtica dioica).

\section{MATERIALS AND METHODS}

\section{Sampling}

The soil and plant samples were collected from eight locations in the Meža Valley. Three were in the town of Žerjav, where a smelter operated until 1990, and five were around Žerjav (distances given in parentheses): Male Braslovče (30 km), Topolščica (20 km), Zavodnje (16 km), Šentvid pri Zavodnju (12 km), and Javorje (4 km) (Figure 1). All locations were at least $10 \mathrm{~m}$ away from the street. The samples were collected in June 2014, when all four plant species were in full bloom. 


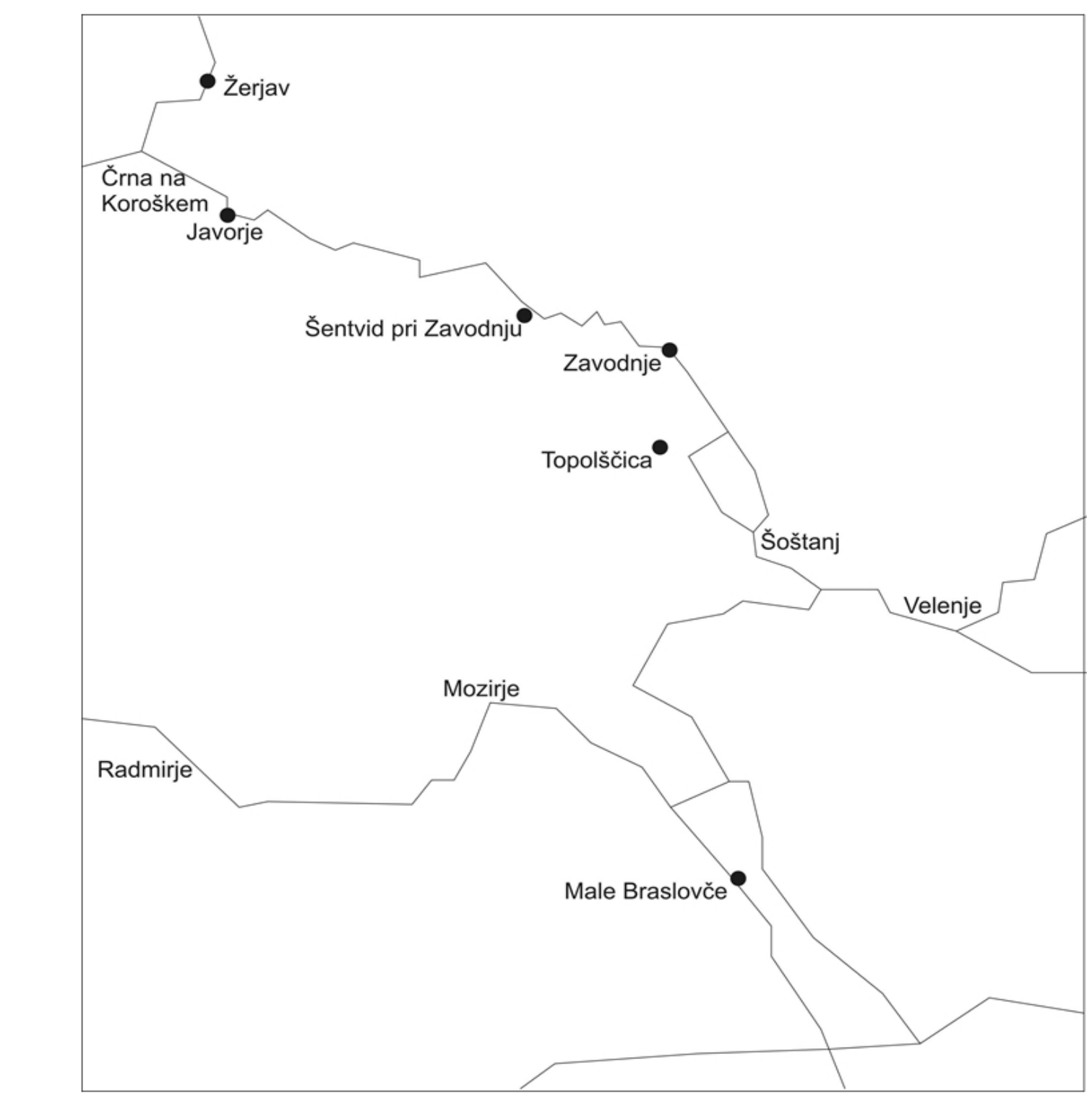

Figure 1 Meža Valley (Slovenia) sampling locations

Only the above-ground parts of the plants (three of each plant species from each location, growing 1 to $3 \mathrm{~m}$ apart) were collected, air-dried at room temperature for seven days, and ground to powder. Plant sample specimens were deposited in the herbarium of the Faculty of Pharmacy, University of Ljubljana, Slovenia.

The soil samples were taken from the same locations as the plant samples at a depth of 5 to $10 \mathrm{~cm}$, air-dried for seven days, ground, and passed through a 2-mm sieve.

\section{Soil acidity}

To determine real $\left[\mathrm{pH}\left(\mathrm{H}_{2} \mathrm{O}\right)\right]$ and potential $[\mathrm{pH}(\mathrm{KCl})]$ acidity, we measured soil $\mathrm{pH}$ in both aqueous and $\mathrm{KCl}$ solutions, respectively, by adding $25 \mathrm{~mL}$ of double-distilled water or $1 \mathrm{~mol} \mathrm{~L}^{-1} \mathrm{KCl}$ to about $10 \mathrm{~g}$ of soil sample. The obtained suspensions were shaken periodically over $30 \mathrm{~min}$, and the $\mathrm{pH}$ was measured. Real acidity is the concentration of $\mathrm{H}^{+}$in a water solution of a soil sample, whereas potential or exchangeable acidity also includes $\mathrm{H}^{+}$adsorbed on the soil colloids. Heavy metals usually have higher availability in acidic soil than in neutral or basic soil $(13,14)$.

\section{Total metals}

The plant and soil samples were digested with closedvessel high-pressure microwave digesters. Prior to digestion, $0.5 \mathrm{~g}$ of each plant sample was additionally dried

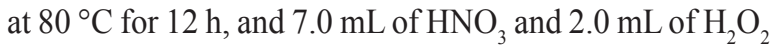
were added. After waiting for $10 \mathrm{~min}$ to avoid the initial vigorous chemical reactions, the samples were digested following the temperature programme described elsewhere (15). A similar procedure was applied to the soil samples: $9.0 \mathrm{~mL}$ of $\mathrm{HCl}$ and $3.0 \mathrm{~mL}$ of $\mathrm{HNO}_{3}$ were added to $0.5 \mathrm{~g}$ of each soil sample.

After cooling, the contents of the vessels containing both the plant and the soil samples were filtered through a Millipore $0.45-\mu \mathrm{m}$ filter. The solutions were quantitatively 
transferred into $50 \mathrm{~mL}$ calibrated flasks and diluted to full volume with double-distilled water.

\section{Exchangeable metals}

Exchangeable cation concentration (cation exchange capacity, CEC) was determined with a single-step extraction procedure by adding $45.0 \mathrm{~mL}$ of $\mathrm{NH}_{4} \mathrm{OAc}\left(1 \mathrm{~mol} \mathrm{~L}^{-1}\right)$ to $1.00 \mathrm{~g}$ of the soil sample and mixing the two for $2 \mathrm{~h}$. The suspensions were left overnight and then filtered. Ammonium exchangeable fraction (Table 2) was calculated as the exchangeable cation concentration divided by the total heavy metal concentration, and was expressed in percentages.

\section{Extraction of plant samples}

A hot water infusion was made by adding $10 \mathrm{~mL}$ of water to $0.5 \mathrm{~g}$ of powdered Urtica dioica sample. We selected this nettle because it is commonly prepared as a cleansing or detox tea in this locality. The sample was then heated in a microwave oven $\left(100{ }^{\circ} \mathrm{C}\right)$, filtered, and diluted to $50 \mathrm{~mL}$. Heavy metal content was determined directly from the undiluted aqueous solution.

\section{Reagents and apparatus}

All reagents were of analytical grade: $\mathrm{HNO}_{3}(65 \%$; Carlo Erba, Rodano, Italy), $\mathrm{H}_{2} \mathrm{O}_{2}(30 \%$; Belinka Perkemija, Ljubljana, Slovenia), $\mathrm{HCl}$ (37\%; Sigma Aldrich, Steinheim, Germany), ethanol (96\%; Scharlau Chemie S.A., Barcelona, Spain), $\mathrm{NH}_{4} \mathrm{OAc}$ (Fluka, Steinheim, Germany). High-purity water (electrical resistivity $>10 \mathrm{M} \Omega \mathrm{cm}$ ) was produced with a Milli-Q system (Millipore, Bedford, MA, USA). Solutions were made using demineralised water (electrical resistivity $18.2 \mathrm{M} \Omega \mathrm{cm}$, toc $<10 \mu \mathrm{g} \mathrm{L}^{-1}$ ) produced with the Milli-Q system. Calibrated solutions were prepared from $1 \mathrm{~g} \mathrm{~L}^{-1}$ stock solutions (Merck, Steinheim, Germany).

The $\mathrm{Cd}$ and $\mathrm{Pb}$ content in all soil and plant extracts was determined with a Perkin Elmer AAnalyst 600 atomic absorption spectrophotometer with a HGA 400 graphite furnace (Waltham, MA, USA) equipped with pyrolytic graphite tubes and temperature programmes that are presented elsewhere $(15,16)$. The concentrations of Fe, $\mathrm{Mn}, \mathrm{Zn}$, and $\mathrm{Cu}$ were determined with a Varian AA240 atomic absorption spectrophotometer (Palo Alto, CA, USA) under optimal conditions using suitable hollow cathode lamps. Signals were measured with a background correction (deuterium lamp) at the optimal flame (A-Ac) height (15, 16).

\section{RESULTS AND DISCUSSION}

\section{Soil contamination}

Table 1 shows the levels of the six measured heavy metals in the Meža Valley. The European Union has not set the limit values for Fe and $\mathrm{Mn}$, as both metals occur naturally in the soil in a relatively large range. The average Mn level in the Earth's upper crust is $650 \mathrm{mg} \mathrm{kg}^{-1}(17)$, and its concentration ranges from 40 to $900 \mathrm{mg} \mathrm{kg}^{-1}$ (18). In the Meža Valley this range is between 617 and $1335 \mathrm{mg} \mathrm{kg}^{-1}$, which is on the upper end of or above the published values. We believe that Mn levels this high are of natural origin and not the result of contamination from the smelter, because they do not correlate with the $\mathrm{Pb}$ and $\mathrm{Zn}$ levels. The concentration range for $\mathrm{Fe}$ is typically 20,000 to $550,000 \mathrm{mg} \mathrm{kg}^{-1}$ (19), but in our study, it keeps at the lower end: 17,092 to $56,272 \mathrm{mg} \mathrm{kg}^{-1}$.

As for the other metals, whose limits have been regulated, $\mathrm{Cu}$ remained below the Slovenian limit of $60 \mathrm{mg} \mathrm{kg}^{-1}$ (20). In contrast, $\mathrm{Cd}, \mathrm{Pb}$, and $\mathrm{Zn}$ were found at alarming levels, exceeding their lower limits 75, 49, and 14 times, respectively, and exceeding the critical limits 6 , 8 , and 4 times, respectively (Table 1). The samples with the highest contamination were collected in the closest vicinity (approximately $300 \mathrm{~m}$ ) of the former smelter.

\section{Soil acidity}

Soil $\mathrm{pH}$ greatly affects heavy metal availability to plants (21). Table 1 shows that the $\mathrm{pH}\left(\mathrm{H}_{2} \mathrm{O}\right)$ and $\mathrm{pH}(\mathrm{KCl})$ ranged

Table 1 Heavy metal levels $\left(\mathrm{mg} \mathrm{kg}^{-1}\right)$ and acidity in soil samples from eight Meža Valley locations [levels above the Slovenian limit (19) are highlighted in bold]

\begin{tabular}{lcccccccc}
\hline Sample & $\mathbf{C d}$ & $\mathbf{P b}$ & $\mathbf{Z n}$ & $\mathbf{C u}$ & $\mathbf{F e}$ & $\mathbf{M n}$ & $\mathbf{p H}\left(\mathbf{H}_{\mathbf{2}} \mathbf{O}\right)$ & $\mathbf{p H}(\mathbf{K C l})$ \\
\hline Male Braslovče & $\mathbf{2 . 3}$ & 68 & 153 & 55.0 & 35,621 & 1280 & 5.70 & 4.70 \\
\hline Topolščica & 0.4 & 45 & 93 & 20.3 & 40,644 & 617 & 6.40 & 4.70 \\
\hline Zavodnje & $\mathbf{1 . 2}$ & 62 & 119 & 29.7 & 41,803 & 915 & 5.90 & 4.45 \\
\hline Šentvid pri Zavodnju & $\mathbf{4 . 0}$ & $\mathbf{1 3 2}$ & $\mathbf{2 7 4}$ & 47.9 & 53,381 & 762 & 6.65 & 5.80 \\
\hline Javorje & $\mathbf{5 . 6}$ & $\mathbf{9 0 8}$ & $\mathbf{2 9 6}$ & 56.3 & 56,272 & 1335 & 6.60 & 5.75 \\
\hline Žerjav 1 & $\mathbf{7 4 . 7}$ & $\mathbf{4 1 3 2}$ & $\mathbf{2 8 4 1}$ & 34.6 & 27,252 & 572 & 7.00 & 6.20 \\
\hline Žerjav 2 & $\mathbf{5 7 . 7}$ & $\mathbf{2 7 8 9}$ & $\mathbf{2 8 1 1}$ & 30.4 & 18,902 & 444 & 7.45 & 6.75 \\
\hline Žerjav 3 & $\mathbf{4 . 7}$ & $\mathbf{3 3 0}$ & 178 & 15.4 & 17,092 & 530 & 7.45 & 6.95 \\
\hline Limit value & 1 & 85 & 200 & 60 & - & - & - & - \\
\hline Critical limit value & 12 & 530 & 720 & 300 & - & - & - & - \\
\hline
\end{tabular}


Table 2 Ammonium exchangeable fraction of heavy metals

\begin{tabular}{lcccccc}
\hline Location & $\mathbf{C d}$ & $\mathbf{P b}$ & $\mathbf{Z n}$ & $\mathbf{C u}$ & $\mathbf{F e}$ & $\mathbf{M n}$ \\
\hline Topolščica & $13.9 \%$ & n.d. & n.d. & $2.3 \%$ & $0.02 \%$ & $0.53 \%$ \\
\hline Žerjav 1 & $30.6 \%$ & $12.8 \%$ & $3.5 \%$ & $13.9 \%$ & $0.05 \%$ & $0.35 \%$ \\
\hline
\end{tabular}

n.d. - not detected

5.70-7.45 and 4.45-6.95, respectively, which makes them moderately acidic to slightly alkaline and confirms earlier reports (9). Heavy metals usually have higher availability in acidic soil than in neutral or basic soil $(13,14)$. However, the availability of heavy metals (except for Mn) was higher in samples with higher $\mathrm{pH}$ (Table 2), but we are aware that their availability depends on many factors other than $\mathrm{pH}$, e.g. mineral composition, redox potential, microbiota of the soil, concentration of soil organic matter, and humic and fulvic acids as potential ligands for metal complexation (22).

\section{Exchangeable fraction of heavy metals in soil samples}

The total soil heavy metal content points to the extent of soil contamination. However, it has long been known that the total content does not correspond to the content available to plants but only its mobile fraction $(23,24)$. The ammonium exchangeable fraction is one of the main mobile fractions usually determined, the others being the soluble, adsorbed, chelated, complexed, insoluble, and other fractions $(25,26)$. We determined the ammonium exchangeable fraction for all heavy metals in the soil samples from Topolščica and Žerjav 1 (Table 2), which were collected in higher amounts to perform additional experiments. Interestingly, $\mathrm{Pb}$ and $\mathrm{Zn}$ had no ammonium exchangeable fraction for samples from Topolščica. However, $\mathrm{Pb}$ and $\mathrm{Zn}$ did accumulate in plants (Table 4). This finding suggests that the ammonium exchangeable fraction is not adequate to determine heavy metals available for plants, as the absence of ammonium exchangeable fraction does not guarantee the safety of plants cultivated in such soil. Other mobile fractions should therefore be considered.

\section{Plant contamination}

Table 3 shows a great variation in the plant heavy metal accumulation capacity (ranging from the lowest in Urtica to the highest in Plantago), considering that all four species were collected from the same eight locations.

One way to show a plant's accumulation capacity is with the ratio of plant and soil heavy metal concentration, also known as bioconcentration factor (Table 4) $(28,29)$. Achillea had the strongest accumulation preference for $\mathrm{Cd}$ and the weakest for $\mathrm{Cu}$. Urtica, in contrast, showed the weakest accumulation of $\mathrm{Cd}$ and the strongest of $\mathrm{Cu}$. The differences in accumulation between the metals were significant, with $\mathrm{Cd}$ being the most and $\mathrm{Fe}$ the least accumulated metal. This variability is in accordance with previous reports $(30,31)$. Due to the variability of naturally accumulated $\mathrm{Cd}$, higher limits may be justified for herbal drugs accumulating $\mathrm{Cd}$, as proposed by Kabelitz et al. (30) and Gasser et al. (31). Concentration of $\mathrm{Cd}, \mathrm{Pb}$ and $\mathrm{Zn}$ in plants correlated significantly to respective concentrations in soil (Figure 2), while no significant correlation was found for $\mathrm{Cu}, \mathrm{Fe}$ and $\mathrm{Mn}$ (Figure 3).

Wherever $\mathrm{Cd}$ exceeded the limit value for soil, so it did in at least some plant species. The same is true for $\mathrm{Pb}$. Only at Topolščica, where none of the soil metals exceeded the limit, were all metals in all plant species below the limit value. This suggests that the soil and plant limit values are well balanced. For $\mathrm{Cd}$, the soil and plant limits are equal $\left(1 \mathrm{mg} \mathrm{kg}^{-1}\right)$, which corresponds to the bioconcentration factor close to 1 (Table 4). For $\mathrm{Pb}$, the soil limit value is 17 times higher than the plant limit (85 and $5 \mathrm{mg} \mathrm{kg}^{-1}$, respectively), which corresponds to the bioconcentration factor of 0.02 to 0.07 (Table 4).

The European Commission (27) limit values for $\mathrm{Pb}$ and $\mathrm{Cd}$ in plants are $1.0 \mathrm{mg} \mathrm{kg}^{-1}$ and $5.0 \mathrm{mg} \mathrm{kg}^{-1}$, respectively. However, the human toxicity threshold proposed by some is higher and spans from 30 to $300 \mathrm{mg} \mathrm{kg}^{-1}$ for $\mathrm{Pb}$ (32) and 5 to $30 \mathrm{mg} \mathrm{kg}^{-1}$ for $\mathrm{Cd}(32,33)$. The $\mathrm{Pb}$ and $\mathrm{Cd}$ concentrations in our study fall within these toxic ranges. They are, however, lower than those found by Gjorgieva et al. (2) for Urtica dioica growing in polluted areas of Macedonia (102.03 mg kg-1 for $\mathrm{Pb}$ and $7.37 \mathrm{mg} \mathrm{kg}^{-1}$ for $\mathrm{Cd}$ ) and comparable to those reported by Nadgórska-Socha et al. (34) for Plantago lanceolata growing in polluted areas of Poland (19.5 to $121.3 \mathrm{mg} \mathrm{kg}^{-1}$ for $\mathrm{Pb}$, and 5.7 to $13.8 \mathrm{mg} \mathrm{kg}^{-1}$ for $\mathrm{Cd}$ ).

Medicinal plants are still widely harvested from wild habitats for individual use and production of plant-based products (35). It is therefore important to emphasize that the safety and benefits of plant-based products are directly related to the quality of the raw materials (36), including the presence of heavy metals within safe limits.

\section{Heavy metals in plant extracts}

A hot water infusion was produced from the Urtica dioica samples from Topolščica and Žerjav 1. Table 5 shows some interesting findings. Even though the Žerjav 1 samples of $U$. dioica had four times higher $\mathrm{Cd}$ levels than the Topolščica samples, their extracts had a similar amount of $\mathrm{Cd}$ ( 0.063 vs. $0.053 \mathrm{mg} \mathrm{kg}^{-1}$, respectively). Similarly, the Žerjav $1 \mathrm{~Pb}$ levels were 15 times higher than the Topolščica levels, yet the extracted $\mathrm{Pb}$ was below the limit of detection in both samples. It seems that heavy metals may bind to plant tissues in an insoluble form.

Heavy metal extraction rates were 7 to $22 \%$ for $\mathrm{Cd}, 47$ to $48 \%$ for $\mathrm{Zn}, 18$ to $19 \%$ for $\mathrm{Cu}, 4$ to $13 \%$ for $\mathrm{Fe}$, and 
Table 3 Heavy metal levels in plant samples $\left(\mathrm{mg} \mathrm{kg}^{-1}\right)$ from eight Meža Valley locations [levels above the European Commission limit (27) are highlighted in bold]

\begin{tabular}{|c|c|c|c|c|c|c|c|}
\hline Plant & Location & Cd & $\mathbf{P b}$ & Zn & $\mathrm{Cu}$ & $\mathrm{Fe}$ & Mn \\
\hline \multirow{8}{*}{$\begin{array}{l}\text { Urtica } \\
\text { dioica }\end{array}$} & Male Braslovče & 0.3 & 2.1 & 29.1 & 15.7 & 157.4 & 30.4 \\
\hline & Topolščica & 0.2 & 1.1 & 29.7 & 9.3 & 190.4 & 310.2 \\
\hline & Zavodnje & 0.3 & 1.3 & 35.6 & 9.2 & 112.6 & 318.0 \\
\hline & Šentvid pri Zavodnju & 0.5 & 6.9 & 40.2 & 18.7 & 162.5 & 17.3 \\
\hline & Javorje & 0.4 & 2.9 & 42.0 & 9.4 & 120.6 & 131.3 \\
\hline & Žerjav 1 & 0.9 & 15.5 & 73.5 & 9.3 & 77.1 & 14.9 \\
\hline & Žerjav 2 & 0.6 & 6.6 & 47.0 & 5.0 & 95.3 & 27.2 \\
\hline & Žerjav 3 & 0.3 & 2.6 & 42.0 & 7.4 & 83.0 & 23.9 \\
\hline \multirow{8}{*}{$\begin{array}{l}\text { Hypericum } \\
\text { perforatum }\end{array}$} & Male Braslovče & 0.6 & 2.3 & 38.1 & 11.7 & 115.0 & 18.3 \\
\hline & Topolščica & 0.4 & 2.1 & 38.1 & 8.3 & 61.1 & 68.8 \\
\hline & Zavodnje & 0.2 & 2.9 & 26.9 & 9.9 & 44.6 & 26.0 \\
\hline & Šentvid pri Zavodnju & 1.2 & 4.7 & 45.3 & 10.9 & 108.8 & 10.9 \\
\hline & Javorje & 4.2 & 5.1 & 44.8 & 7.6 & 53.4 & 75.4 \\
\hline & Žerjav 1 & 1.0 & 25.1 & 103.4 & 8.8 & 66.2 & 12.4 \\
\hline & Žerjav 2 & 1.5 & 7.0 & 76.0 & 6.3 & 32.2 & 7.8 \\
\hline & Žerjav 3 & 1.0 & 11.5 & 92.1 & 7.0 & 52.5 & 16.3 \\
\hline \multirow{8}{*}{$\begin{array}{l}\text { Achillea } \\
\text { millefolium }\end{array}$} & Male Braslovče & 1.2 & 1.5 & 23.2 & 9.6 & 145.5 & 35.2 \\
\hline & Topolščica & 0.3 & 2.5 & 30.1 & 7.0 & 121.0 & 24.4 \\
\hline & Zavodnje & 3.5 & 2.1 & 31.1 & 4.2 & 80.9 & 163.2 \\
\hline & Šentvid pri Zavodnju & 2.6 & 3.6 & 35.3 & 9.5 & 89.3 & 19.4 \\
\hline & Javorje & 1.56 & 3.8 & 34.0 & 5.2 & 47.8 & 36.7 \\
\hline & Žerjav 1 & 5.7 & 15.9 & 211.7 & 4.5 & 86.2 & 45.4 \\
\hline & Žerjav 2 & 5.5 & 10.8 & 156.7 & 9.9 & 59.8 & 16.6 \\
\hline & Žerjav 3 & 3.9 & 9.9 & 117.4 & 9.2 & 77.4 & 38.6 \\
\hline \multirow{8}{*}{$\begin{array}{l}\text { Plantago } \\
\text { lanceolata }\end{array}$} & Male Braslovče & 0.5 & 3.1 & 46.5 & 4.2 & 59.4 & 10.3 \\
\hline & Topolščica & 0.8 & 1.4 & 33.3 & 8.1 & 151.7 & 39.7 \\
\hline & Zavodnje & 1.1 & 3.5 & 48.5 & 7.1 & 58.5 & 75.4 \\
\hline & Šentvid pri Zavodnju & 0.3 & 3.9 & 51.8 & 8.1 & 262.0 & 23.2 \\
\hline & Javorje & 3.4 & 107.4 & 104.4 & 9.3 & 122.0 & 56.7 \\
\hline & Žerjav 1 & 0.9 & 48.3 & 147.8 & 7.1 & 175.0 & 23.3 \\
\hline & Žerjav 2 & 16.0 & 195.9 & 799.5 & 8.2 & 338.7 & 33.2 \\
\hline & Žerjav 3 & 2.7 & 61.0 & 127.4 & 10.2 & 112.1 & 16.7 \\
\hline \multicolumn{2}{|c|}{ Limit value (European Commission) } & 1.0 & 5.0 & - & - & - & - \\
\hline
\end{tabular}

$8 \%$ for Mn. Such variability is in line with earlier reports [1.9 to $35 \%$ for $\mathrm{Cu}$ and 8.6 to $10 \%$ for $\mathrm{Mn}(37), 20$ to $50 \%$ for $\mathrm{Mn}$ and $\mathrm{Zn}$ (38), $9 \%$ for Fe and $5 \%$ for $\mathrm{Mn}(39)$, and $6 \%$ for Fe, $24 \%$ for $\mathrm{Mn}$, and $35 \%$ for $\mathrm{Zn} \mathrm{(40)].}$

Judging by the $\mathrm{Cd}$ level in the $U$. dioica hot water infusion, by drinking one litre of tea (equivalent to $10 \mathrm{~g}$ of the dried plant) a day for seven days a 70-kg person would not exceed the acceptable weekly intake. Similar calculations for $\mathrm{Zn}, \mathrm{Cu}, \mathrm{Fe}$, and $\mathrm{Mn}$ show that $U$. dioica from Topolščica and Žerjav is suitable for medicinal and nutritional use, especially if the washing procedure is followed, as it can considerably reduce heavy metal content $(41,42)$.

\section{CONCLUSIONS}

Regular evaluation of environmental conditions in areas affected with mining and smelting pollution is of great importance. Not only should it include the total content of heavy metals in the soil, which shows the extent of soil contamination, but also their content in plants, which indicates human exposure. Our findings show alarming concentrations of $\mathrm{Cd}, \mathrm{Pb}$, and $\mathrm{Zn}$ in the Meža Valley soil, while $\mathrm{Mn}, \mathrm{Fe}$, and $\mathrm{Cu}$ did not exceed the limits. None of the studied plant species strongly accumulates all the metals, but $\mathrm{Cd}$ stands out as the most accumulated metal. Fortunately, heavy metal extraction (with hot water infusion 


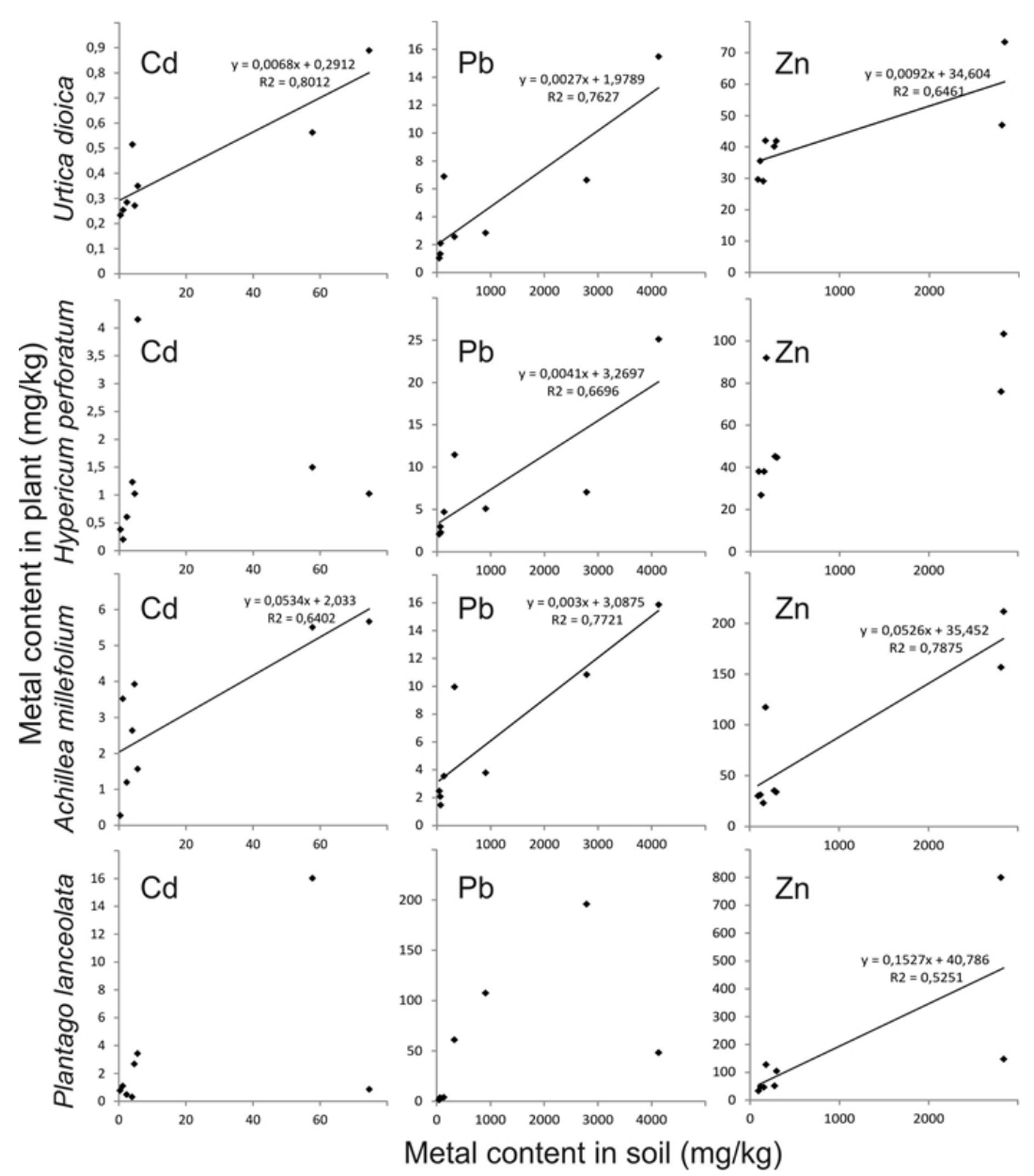

Figure $2 \mathrm{Cd}, \mathrm{Pb}$, and $\mathrm{Zn}$ plant levels in relation to their levels in soil. Regression lines are drawn for all metals and plant species for which the Pearson correlation was significant $(p<0.05)$

Table 4 Bioconcentration factors for the heavy metals and plant species (averages of eight locations).

\begin{tabular}{lccccc} 
& U. dioica & H. perforatum & A. millefolium & P. lanceolata & all species \\
\hline $\mathrm{Cd}$ & $0.15 \pm 0.19$ & $0.34 \pm 0.34$ & $0.77 \pm 0.93$ & $0.58 \pm 0.64$ & $0.46 \pm 0.62$ \\
\hline $\mathrm{Pb}$ & $0.02 \pm 0.02$ & $0.03 \pm 0.02$ & $0.02 \pm 0.02$ & $0.07 \pm 0.06$ & $0.03 \pm 0.04$ \\
\hline $\mathrm{Zn}$ & $0.17 \pm 0.11$ & $0.22 \pm 0.17$ & $0.22 \pm 0.2$ & $0.33 \pm 0.19$ & $0.24 \pm 0.17$ \\
\hline $\mathrm{Cu}$ & $0.31 \pm 0.12$ & $0.28 \pm 0.11$ & $0.25 \pm 0.17$ & $0.27 \pm 0.18$ & $0.28 \pm 0.14$ \\
\hline $\mathrm{Fe}$ & $0.004 \pm 0.001$ & $0.002 \pm 0.001$ & $0.003 \pm 0.001$ & $0.006 \pm 0.005$ & $0.004 \pm 0.003$ \\
\hline $\mathrm{Mn}$ & $0.14 \pm 0.18$ & $0.04 \pm 0.03$ & $0.06 \pm 0.05$ & $0.05 \pm 0.03$ & $0.07 \pm 0.1$ \\
\hline $\mathrm{All}$ metals & $0.13 \pm 0.16$ & $0.15 \pm 0.2$ & $0.22 \pm 0.46$ & $0.22 \pm 0.34$ & $0.18 \pm 0.31$
\end{tabular}

Table 5 Levels of heavy metals extracted by hot water from Urtica dioica expressed per $\mathrm{kg}$ of herbal drug $\left(\mathrm{mg} \mathrm{kg}^{-1}, n=3\right)$

\begin{tabular}{lcccccc}
\hline Location & $\mathbf{C d}$ & $\mathbf{P b}$ & $\mathbf{Z n}$ & $\mathbf{C u}$ & $\mathbf{F e}$ & $\mathbf{M n}$ \\
\hline Topolšcica & 0.05 & $* 0$ & 14.39 & 1.64 & 7.51 & 26.20 \\
\hline Žerjav 1 & 0.06 & $* 0$ & 34.56 & 1.79 & 9.96 & $* 0$ \\
\hline${ }^{1} \mathrm{RDA} /{ }^{2} \mathrm{TWI}$ & ${ }^{2} 0.0025^{* *}$ & ${ }^{2} 3$ & ${ }^{1} 8-11$ & ${ }^{1} 0.7-0.8$ & ${ }^{1} 8-18 * * *$ & ${ }^{1} 1.6-2.3$
\end{tabular}

$R D A$ - recommended dietary allowances in $\mathrm{mg} \mathrm{day}^{-1} ; \mathrm{TWI}$ - tolerable weekly intake in $\mathrm{mg}$ week ${ }^{-1}$; ${ }^{*}$ Below the limit of detection; $* * T W I$ per $\mathrm{kg}$ of body mass; ***Recommended intake assumes $75 \%$ of iron is from haem iron sources 


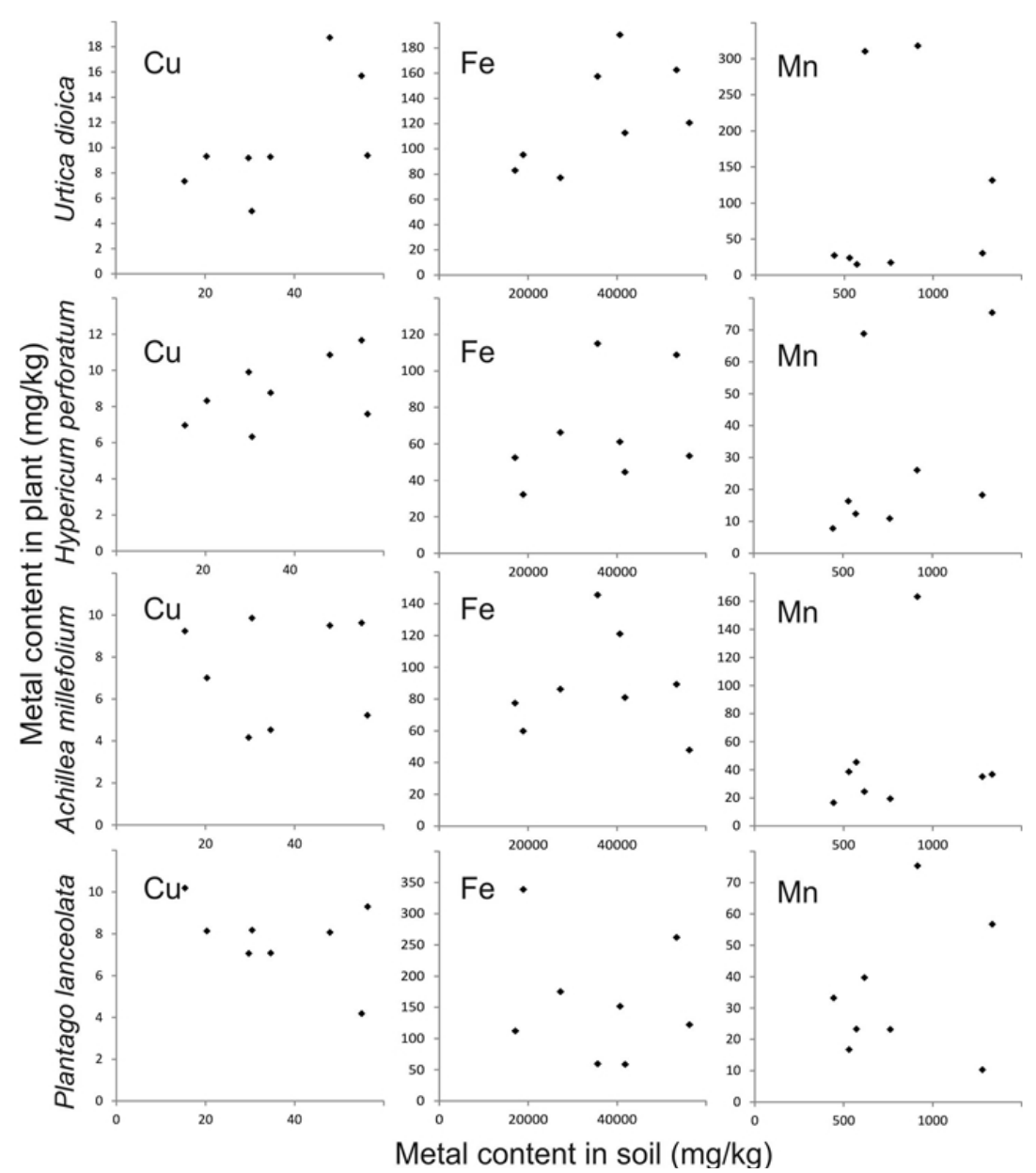

Figure $3 \mathrm{Cu}, \mathrm{Fe}$, and $\mathrm{Mn}$ plant levels in relation to their levels in soil. The Pearson correlation was not significant ( $p<0.05)$ for any of the metals in any of the investigated plant species

in our case) was low, which suggests that heavy metals bind to plant tissues in an insoluble form. Further research should help to better understand heavy metal transport from soil to plants and from plants to plant extracts.

\section{Conflicts of interest}

None to be declared.

\section{REFERENCES}

1. Barthwal J, Nair S, Kakkar P. Heavy metal accumulation in medicinal plants collected from environmentally different sites. Biomed Environ Sci 2008;21:319-24. doi: 10.1016 S0895-3988(08)60049-5

2. Gjorgieva D, Kadifkova-Panovska T, Bačeva K, Stafilov T. Content of toxic and essential metals in medicinal herbs growing in polluted and unpolluted areas of Macedonia. Arh Hig Rada Toksikol 2010;61:297-303. doi: 10.2478/100041254-61-2010-2022

3. Kulhari A, Sheorayan A, Bajar S, Sarkar S, Chaudhury A, Kalia RK. Investigation of heavy metals in frequently utilized medicinal plants collected from environmentally diverse locations of north western India. Springerplus 2013;2:676 doi: 10.1186/2193-1801-2-676
4. Kosalec I, Cvek J, Tomić S. Contaminants of medicinal herbs and herbal products. Arh Hig Rada Toksikol 2009;60:485501. doi: 10.2478/10004-1254-60-2009-2005.

5. Manousaki E, Kalogerakis N. Phytoextraction of $\mathrm{Pb}$ and $\mathrm{Cd}$ by the Mediterranean saltbush (Atriplex halimus L.): metal uptake in relation to salinity. Environ Sci Pollut Res Int 2009;16:844-54. doi: 10.1007/s11356-009-0224-3

6. Fux J, Gosar M. Vsebnosti svinca in drugih težkih kovin v sedimentih na območju Mežiške doline [Lead and other heavy metals in stream sediments in the area of Meža valley, in Slovenian]. Geologija 2007;50:347-60. doi: 10.5474/ geologija.2007.025

7. Eržen I, Janet E. Svinec v krvi tri leta starih otrok, ki živijo na območju Zgornje in Spodnje Mežiške doline [Blood lead concentrations in three-year-old children living of the Upper and Lower Mežica valley, in Slovenian]. Zdrav Var 2005;44:18-25.

8. Ivartnik M, Eržen I. Uporaba modela IEUBK za napoved vsebnosti svinca v krvi otrok pri raziskavah in sanaciji okolja v Zgornji Mežiški dolini [The IEUBK model for lead blood burden prediction in children used in the exploration and remediation of the Upper Meža Valley environment, in Slovenian]. Zdrav Var 2010;49:76-85.

9. Finžgar N, Leštan D. Ocena dostopnosti težkih kovin iz onesnaženih tal Mežiške doline [Evaluation of heavy metals 
accessibility in poluted soils from Mežica valley, in Slovenian]. Acta Agric Slov 2008;91:157-66.

10. Vidic T, Lah B, Berden-Zrimec M, Marinsek-Logar R. Bioassays for evaluating the water-extractable genotoxic and toxic potential of soils polluted by metal smelters. Environ Toxicol 2009;24:472-83. doi: 10.1002/tox.20451

11. Prpić-Majić D, Pongračić J, Hršak J, Pizent A. A follow-up study in a lead smelter community following the introduction of an effective pollution control system. Isr J Med Sci 1992;28:548-56. PMID: 1428809

12. Prpić-Majić D, Fugaš M, Souvent P, Sušnik J, Šarić M. Istraživanja olova, kadmija i cinka u dolini rijeke Meže. Zagreb: Institut za medicinska istraživanja i medicinu rada; 1996.

13. Karalić K, Lončarić Z, Popović B, Zebec V, Kerovec D. Liming effect on soil heavy metals availability. Poljoprivreda 2013;19:59-64

14. Kashem MA, Singh BR. Metal availability in contaminated soils: I. Effects of flooding and organic matter on changes in Eh, pH and solubility of $\mathrm{Cd}, \mathrm{Ni}$ and $\mathrm{Zn}$. Nutr Cycling Agroecosyst 2001;61:247-55. doi: 10.1023/A:1013762204510

15. Ražić S, Đogo S, Slavković L. Multivariate characterization of herbal drugs and rhizospere soil samples according to their metallic content. Microchem J 2006;84:93-101. doi: 10.1016/j.microc.2006.05.008

16. Vandecasteele C, Block CB. Modern Methods for Trace Element Determination. New York: John Wiley \& Sons; 1997.

17. Gilkes RJ, McKenzie RM. Geochemistry and mineralogy of manganese in soils. In: Graham RD, Hannam RJ, Uren NC, editors. Manganese in soils and plants. Dordrecht: Kluwer Academic Publishers; 1988. p. 23-35.

18. United States Environmental Protection Agency (US EPA). Health Effects Notebook for Hazardous Air Pollutants [displayed 5 May 2017]. Available at https://www.epa.gov/ haps/health-effects-notebook-hazardous-air-pollutants

19. United States Environmental Protection Agency (US EPA). Ecological Soil Screening Level for Iron, Interim Final OSWER Directive 9285.7-69, 2003 [displayed 6 December 2016]. Available at http://rais.ornl.gov/documents/eco-ssl_ iron.pdf

20. Uradni list RS (UL). Uredba o mejnih, opozorilnih in kritičnih imisijskih vrednostih nevarnih snovi v tleh, stran 5773 [Decree on limit values, alert thresholds, and critical levels of dangerous substances in soil, in Slovenian] [displayed 5 May 2017]. Available at http://www.uradni-list.si/1/ content?id=12912

21. Kabata-Pendias A. Trace Elements in Soils and Plants. 4th ed. Boca Raton: Taylor and Francis Group; 2011.

22. Rieuwerts JS, Thornton I, Farago ME, Ashmore MR. Factors influencing metal bioavailability in soils: preliminary investigations for the development of a critical loads approach for metals. Chem Spec Bioavailab 1998;10(2):61-75. doi: 10.3184/095422998782775835.

23. Cataldo DA, Wildung RE. Soil and plant factors influencing the accumulation of heavy metals by plants. Environ Health Perspect 1978;27:149-59. doi: 10.2307/3428874

24. Symeonides A, McRae SS. The assessment of plant-available cadmium in soils. J Environ Qual 1977;6:120-2. doi: 10.2134/ jeq1977.00472425000600020003x

25. Maiz I, Arambarri I, Garcia R, Millán E. Evaluation of heavy metal availability in polluted soils by two sequential extraction procedures using factor analysis. Environ Pollut 2000;110:3-9. doi: 10.1016/S0269-7491(99)00287-0

26. Viets FG Jr. Micronutrient availability, chemistry and availability of micronutrients in soils. J Agric Food Chem 1962;10:174-8. doi: 10.1021/jf60121a004

27. European Commission (EC). Commission regulation (EC) No 1881/2006 of 19 December 2006 setting maximum levels for certain contaminants in foodstuffs (Text with EEA relevance) (OJ L 364, 20.12.2006, p. 5) [displayed 5 May 2017]. Available at http://eur-lex.europa.eu/legal-content/ $\mathrm{EN} / \mathrm{TXT} / \mathrm{PDF} /$ ? uri=CELEX:02006R 1881 20100701\&from=EN

28. Ražić S, Đogo S. Determination of chromium in Mentha piperita L. and soil by graphite furnace atomic absorption spectrometry after sequential extraction and microwave acid assisted digestion to assess potential bioavailability. Chemosphere 2010;78:451-6. doi: 10.1016/j. chemosphere.2009.10.028

29. Wang XP, Shan XQ, Zhang SZ, Wen B. A model for evaluation of the phytoavailability of trace elements to vegetables under the field conditions. Chemosphere 2004;55:811-22. doi: 10.1016/j.chemosphere.2003.12.003

30. Kabelitz L. Zur Schwermetallbelastung von Arznei- und Kräuterdrogen [Heavy metals in herbal drugs, in German]. Pharm Ind 1998;60:444-51.

31. Gasser U, Klier B, Kühn AV, Steinhoff B. Current findings on the heavy metal content in herbal drugs. Pharmeur Sci Notes 2009;1:37-50. PMID: 19275871

32. Kloke A, Sauerbeck DC, Vetter H. The contamination of plants and soils with heavy metals and the transport of metals in terrestrial food chains. In: Nriagu JO, editor. Changing Metal Cycles and Human Health. Dahlem Workshop Reports, Life Sciences Research Report, Vol 28; 20-25 March 1983; Berlin, Germany. Berlin, Heidelberg: Springer; 1984. p. 131-41.

33. Allen SE, editor. Chemical Analysis of Ecological Materials. 2nd ed. Oxford: Blackwell Science Inc.; 1989.

34. Nadgórska-Socha A, Ptasiński B, Kita A. Heavy metal bioaccumulation and antioxidative responses in Cardaminopsis arenosa and Plantago lanceolata leaves from metalliferous and non-metalliferous sites: a field study. Ecotoxicology 2013;22:1422-34. doi: 10.1007/s10646-013$1129-\mathrm{y}$

35. Sarma H, Deka S, Deka H, Saikia RR. Accumulation of heavy metals in selected medicinal plants. Rev Environ Contam Toxicol 2011;214:63-86. doi: 10.1007/978-1-4614-0668-6 4

36. Salgueiro L, Martins AP, Correia H. Raw materials: the importance of quality and safety. A review. Flavour Fragrance J 2010;25:253-71. doi: 10.1002/ffj.1973

37. Konieczyński P, Wesołowski M. Water-extractable magnesium, manganese and copper in leaves and herbs of medicinal plants. Acta Pol Pharm 2012;69:33-9. PMID: 22574504

38. Weber G, Konieczyński P. Speciation of Mg, Mn and $\mathrm{Zn}$ in extracts of medicinal plants. Anal Bioanal Chem 2003;375:1067-73. doi: 10.1007/s00216-002-1706-z

39. Islam MA, Ebihara M. Elemental characterization of Japanese green tea leaves and tea infusion residue by neutroninduced prompt and delayed gamma-ray analysis. Arab J Chem 2017;10(Supp 1):S677-82. doi: 10.1016/j. arabjc.2012.11.008 
40. Gallaher RN, Gallaher K, Marshall AJ, Marshall AC. Mineral analysis of ten types of commercially available tea. J Food Compos Anal 2006;19(Suppl):S53-7. doi: 10.1016/j. jfca.2006.02.006

41. Keane B, Collier MH, Shann JR, Rogstad SH. Metal content of dandelion (Taraxacum officinale) leaves in relation to soil contamination and airborne particulate matter. Sci Total
Environ 2001;281:63-78. doi: 10.1016/S00489697(01)00836-1

42. Kos V, Budic B, Hudnik V, Lobnik F, Zupan M. Determination of heavy metal concentrations in plants exposed to different degrees of pollution using ICP-AES. Anal Bioanal Chem 1996;354:648-52. doi: 10.1007/s0021663540648

\section{Kopičenje težkih kovin iz tal v zdravilnih rastlinah}

Težke kovine iz onesnaženih tal se kopičijo v zdravilnih rastlinah, zaradi česar lahko njihovo uživanje privede do zastrupitev. Namen naše raziskave je bil ugotoviti vsebnosti svinca, kadmija, cinka, bakra, železa in mangana v vzorcih tal ter v vzorcih navadnega rmana (Achillea millefolium), šentjanževke (Hypericum perforatum), ozkolistnega trpotca (Plantago lanceolata) in velike koprive (Urtica dioica), nabranih na osmih lokacijah v Mežiški dolini. Koncentracije kadmija, svinca in cinka so kritično presegale mejne vrednosti. Vsebnost teh treh težkih kovin je značilno korelirala z njihovo vsebnostjo $\mathrm{v}$ proučevanih rastlinah, ki pa posamezne težke kovine kopičijo v različnem obsegu. Različen je bil tudi obseg njihove ekstrakcije v vročo vodo. Naša raziskava prispeva pomembne rezultate za nadaljnje proučevanje povezav med prehajanjem težkih kovin iz (onesnaženih) tal v rastline in rastlinske izvlečke. Poleg tega nakazuje tudi na izjemen pomen rednega spremljanja stanja tal, zlasti na področjih kritične onesnaženosti, saj je nabiranje zdravilnih rastlin v naravi v današnjem času izjemno priljubljeno.

KLJUČNE BESEDE: baker; cink; kadmij; kopriva; Mežiška dolina; rman; svinec; šentjanževka; trpotec; železo 